\title{
Flesh flies species (Diptera: Sarcophagidae) from a grassland and a woodland in a Nature Reserve of Buenos Aires, Argentina
}

\author{
Pablo R. Mulieri ${ }^{1}$, Juan A. Schnack ${ }^{2}$, Juan C. Mariluis ${ }^{3} \&$ Juan P. Torretta ${ }^{4}$
}

1. ANLIS "Dr. Carlos Malbrán” Departamento de Vectores, Av. Velez Sarsfield 563 (1281), Buenos Aires, Argentina; mulierii@yahoo.com

2. División Entomología, Facultad de Ciencias Naturales y Museo, Universidad Nacional de La Plata, Paseo del Bosque s/n 1900 La Plata, Argentina; js@netverk.com.ar

3. ANLIS “Dr. Carlos Malbrán” Departamento de Vectores, Av. Velez Sarsfield 563 (1281), Buenos Aires, Argentina; jcmariluis@yahoo.com.ar

4. Cátedra de Botánica Agrícola, Facultad de Agronomía, Universidad de Buenos Aires, Av. San Martín 4453 (1417) Buenos Aires, Argentina; torretta@agro.uba.ar

Received 06-XII-2006. Corrected 30-VI-2008. Accepted 31-VII-2008.

\begin{abstract}
Temporal changes of flesh flies abundance were simultaneously recorded at monthly intervals during a year in a woodland and in a grassland at the "Reserva Ecológica Costanera Sur" (RECS), Buenos Aires city, Argentina. Samples were taken at monthly intervals (February 2004-January 2005). Hourly captures of adult flies (10:00 am - 04:00 pm) were taken each sampling date with a hand net. Temperature was recorded at each hourly capture. The baits used were $200 \mathrm{~g}$ of rotten cow liver and $200 \mathrm{~g}$ of fresh dog faeces. Records of abundance included only species whose abundance was $\geq 30$ individuals accumulated during the whole sampling period. Considering overall abundance, a non-parametric Chi-square test was used to estimate deviations of an expected habitat and bait preference ratios of $1: 1$. The same criterion was applied to include species in a contingency table to describe their seasonality. The final matrix included four species whose associations to seasons were analyzed by using a Correspondence Analysis. To normalize the data, a $\log _{10}(\mathrm{n}+1)$ transformation was applied prior to the analysis of correlation. Pearson product-moment correlations were used to examine the relationship between flesh-fly abundance with temperature and habitat preference. The entire sample accumulated 1305 individuals and 18 species. The flies were more abundant in the grassland than in the woodland. Microcerella muehni, Oxysarcodexia paulistanensis, O. varia and Tricharaea (Sarcophagula) occidua exhibited the higher relative abundance, representing the remaining species less than $8 \%$ of the entire sample. Most of the recorded species showed preference for faces as bait. Concerning the dominant species, all of them but $M$. muehni, a suggestively termophobic species, prevailed in late spring-summer. The observed species arrangement at both sites indicates low species diversity and equitability and high information per individual in the average. The referred community traits would indicate the possible effects of environmental disturbance due to the proximity of study sites to dense urban settlements. Rev. Biol. Trop. 56 (3): 1287-1294. Epub 2008 September 30.
\end{abstract}

Key words: Sarcophagidae, Buenos Aires, grassland, woodland, species composition, seasonal abundance.

Flesh flies (Diptera: Sarcophagidae) are typically saprophagous and frequently found associated to ephemeral resources, like carrion and faeces (Ives 1991, Mendes and Linhares 1993). Nowadays, few ecological studies of Sarcophagidae species are known for the Neotropics, being the current knowledge of their seasonal trends in this region mostly restricted to subtropical and temperate areas of
Brazil (Ferreira 1979, Linhares 1981, Dias et al. 1984a,b, Mendes and Linhares 1993).

From the sanitary viewpoint, flesh flies are of relevant importance. Their impact on human and animal health is well known for their potential ability as myiasis producers (Mazza et al. 1930, Mazza and Basso 1939, Zumpt 1965, Guimarães et al. 1983) and for their role as vector of pathogens (Greenberg 1971). On 
the other hand, Sarcophagidae are among the most useful insects for forensic investigations (Wells et al. 2001).

This work is aimed at improving the knowledge of Sarcophagidae species occurring at the coastline of Buenos Aires, taking into account their seasonal trends in abundance and habitat and bait preferences, regarding two contrasting sites: a woodland and a grassland, both enclosed in a protected area whose eastern and western borders are spatially connected with the Río de la Plata and with a dense urban section, respectively.

\section{MATERIALS AND METHODS}

Study sites: this study was carried out in the "Reserva Ecológica Costanera Sur" (RECS) ( $\left.34^{\circ} 37^{\prime} \mathrm{S}-58^{\circ} 21^{\prime} \mathrm{W}\right)$, a protected area covering $343 \mathrm{ha}$, which is located in the eastern border of Buenos Aires city, adjacent to Rio de la Plata. The climate in the study area is temperate and humid, with an annual mean temperature of $17.6^{\circ} \mathrm{C}$ and an accumulated rainfall of about 1 $200 \mathrm{~mm} /$ year.

Surveyed habitats: two types of habitats were simultaneously sampled. One of them comprised a grassland habitat with direct sunlight incidence, where graminoids plants (e.g. Stipa, Pitocmaetium, Aristida, Melisa, Brisa, and Bromus), and the emergent marsh plant, Cortaderia selloana (Schult. \& Schult. F.) Asch. \& Graebn. (Poaceae) were the most abundant. The other surveyed habitat was a shadowed woodland where Tessaria integrifolia Ruiz et Pavón (Asteraceae), Salix humboldtiana Willd (Salicaceae), and Baccharis salicifolia Ruiz et Pavon (Asteraceae) were dominant.

Sampling: monthly samplings were carried out from February 2004 to January 2005. Seven hourly captures of adult flies (10:00 am $-04: 00 \mathrm{pm}$ ) were taken with a hand net and two different kinds of baits for each type of habitat. Ambient temperature was recorded at each sampling time. The baits used were composed by $200 \mathrm{~g}$ of rotten cow liver (five days aged to ambient temperature) and $200 \mathrm{~g}$ of fresh dog faeces. Each kind of bait was separated from the other by $30 \mathrm{~m}$ and exposed during $15 \mathrm{~min}$ to fly colonization each time. Both sites were 100 $\mathrm{m}$ apart from each other. The baits were kept into closed recipients after each capture. Flies were killed by means of glass vials with carbon tetrachloride at field, and were identified in a laboratory. Identification was made following Blanchard $(1939,1942)$ and Lopes and Tibana (1987). Nomenclature status of species was based on Pape (1996).

Data analysis: data of abundance included only those species represented by no less than 30 individuals accumulated during the entire sampling period. Based upon overall abundance, a non-parametric Chi-square test was used to estimate deviations of an expected habitat and bait preference ratios of 1:1 (Zar 1996). The same criterion was applied to include species in a contingency table to describe species seasonality. Total number of flies captured in the two habitats was summed in this table. The final matrix included four species whose associations to seasons were analyzed by using a Correspondence Analysis (CA).

To normalize the data, a $\log _{10}(\mathrm{n}+1)$ transformation was applied prior to the analysis of correlation. Pearson product-moment correlations were used to examine the relationship between flesh-fly abundance and temperature, and flesh fly abundance and habitat preference (Zar 1996).

\section{RESULTS}

Overall abundance: during the sampled year a total of 1305 flesh flies from eighteen different species were obtained (Table 1). The presence of flies was recorded throughout the year in both surveyed sites. The number of flesh flies increased gradually during the warmer months reaching the highest records in February, decreasing dramatically between April and July. Overall number of captures was higher in the grassland than in the woodland for each date (Fig. 1). However, numerical 


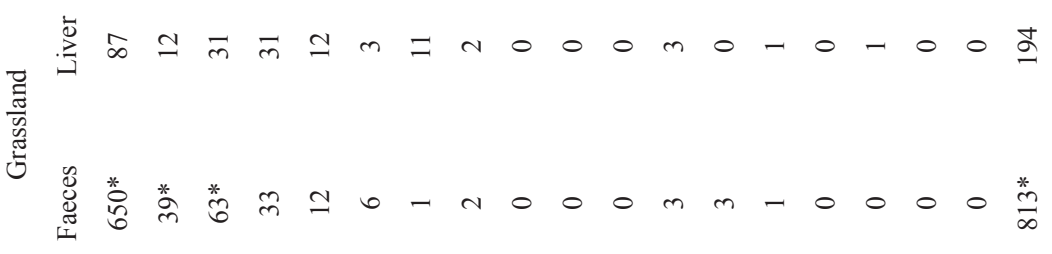

离 $\frac{\sqrt{3}}{\bar{z}}$

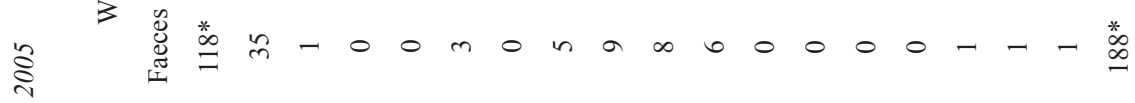

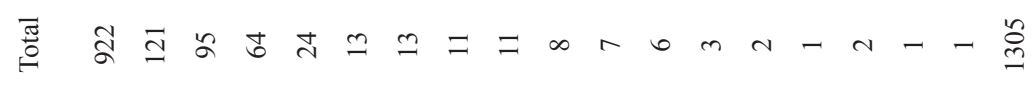

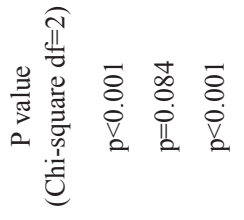

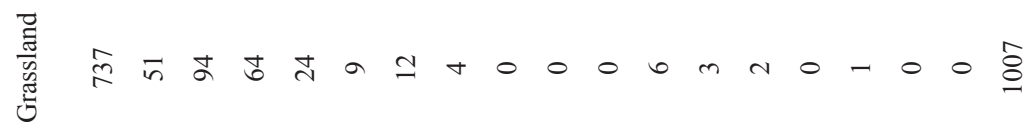

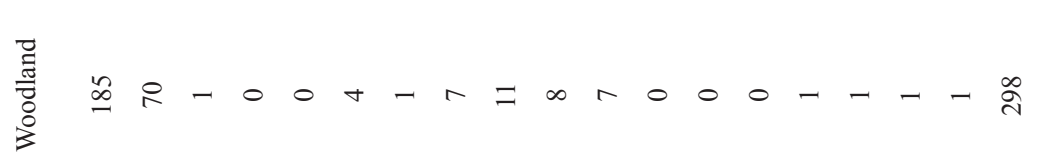

$\dot{8}$
$\dot{0}$
0
$\ddot{0}$
$\frac{\pi}{0}$
$\dot{0}$

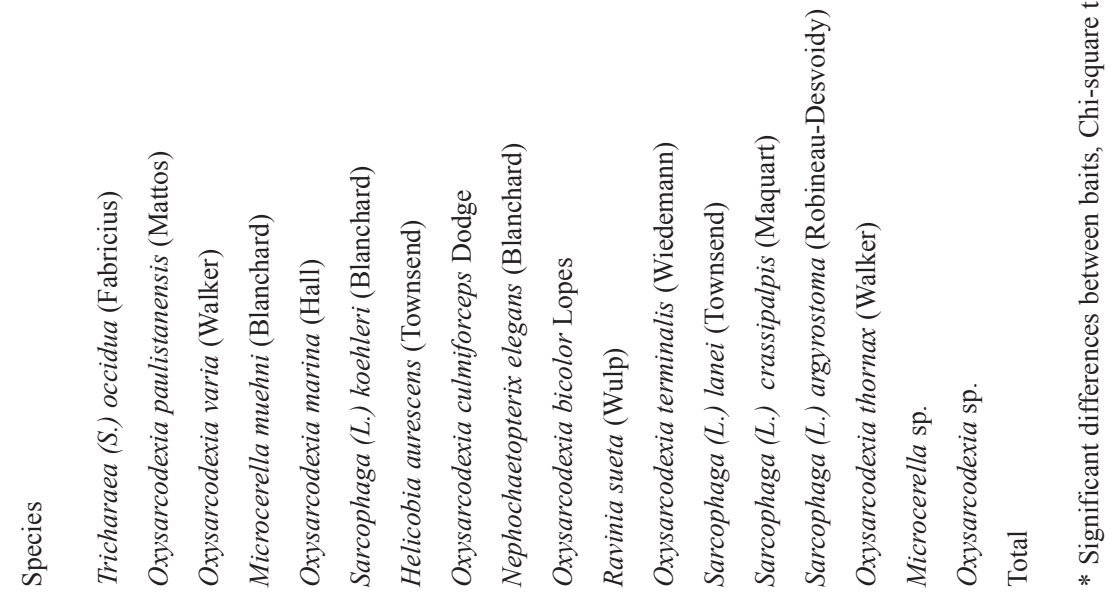




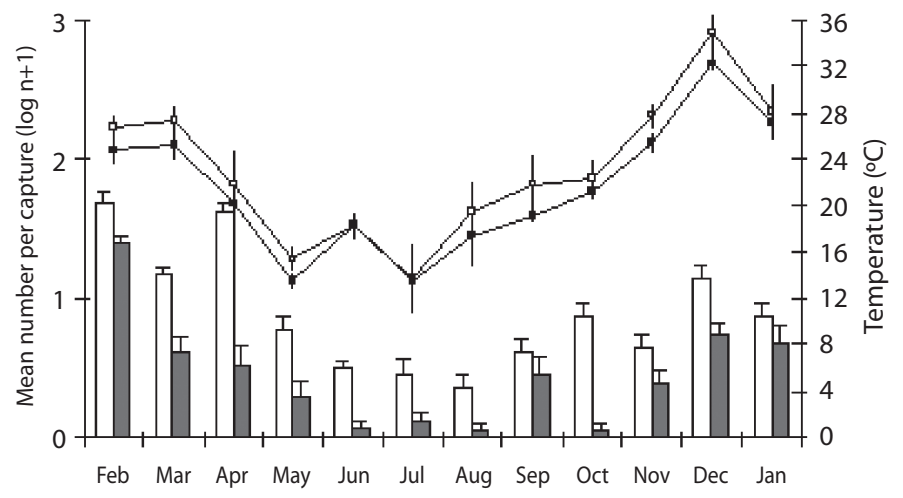

Fig. 1. Seasonal abundance (mean $\pm \mathrm{SE}$ ) of total Sarcophagidae captured in the woodland (black bars) and grassland habitat (white bars), and recorded temperature (mean $\pm \mathrm{SE}$ ) (woodland: black squares, grassland habitat: white squares) at RECS (February 2004-January 2005).

seasonal trends were positively and significantly correlated at both sites $(\mathrm{r}=0.64, \mathrm{~N}=83$, $\mathrm{p}<0.05$ ).

Species relative abundance and habitat preference: from the 18 recorded species, Microcerella muehni (Blanchard 1935), Oxysarcodexia paulistanensis (Mattos 1919), O. varia (Walker 1836) and Tricharaea (Sarcophagula) occidua (Fabricius 1794) showed the higher relative abundance, representing the remaining species less than $8 \%$ of the entire sample. Regarding the whole number of flies captured throughout the year, $T$. (S.) occidua was highly dominant in the grassland $(73.2 \%)$ and in the woodland as well $(62.1$ $\%$ ). However, this species showed the higher abundance during the warmer time of year, and its occurrence was remarkable from October to June, reaching its highest numbers in February (Fig. 2A). Oxysarcodexia paulistanensis and $O$. varia, showed their highest abundance in December and February, respectively (Fig. 2B, C). On the other hand, M. muehni displayed a different seasonal pattern, being dominant over the remaining species during winter and reaching its highest abundance in September and October (Fig. 2D).

The ordination diagram of the CA analysis (Fig. 3) displays the Eigenvalues of axis I and II, which were 0.38 and 0.04 respectively. In fact, Axis I account for the $90 \%$ of the total variance. As shown in the diagram the highest abundance of $T$. (S.) occidua and $O$. paulistanensis was reached in summer and fall and secondarily in spring, while $O$. varia was more abundant in spring time. Conversely, $M$. muehni exhibited high abundance in samples taken in winter.

In a wide sense, flesh fly community showed a higher association to the grassland than to the woodland $(\chi 2=385.19, \mathrm{df}=1$, $\mathrm{p}<0.001)$. The same results were obtained at species levels for $T$. (S.) occidua $(\chi 2=330.48$, $\mathrm{df}=1, \mathrm{p}<0.001)$ and $O$. varia $(\chi 2=91.04, \mathrm{df}=1$, $\mathrm{p}<0.001)$, while a clear trend was not found for $O$. paulistanensis $(\chi 2=2.98, \mathrm{df}=1, \mathrm{p}=0.084)$ (Table 1). It was observed that M. muehni had a strong association only with the grassland habitat (Table 1).

Species bait's preference: comparisons between baits showed higher overall number of flies captured on faeces than on liver. This trend is maintained for the dominant species at both habitats with the exception of $O$. paulistanensis which exhibited similar preference for both baits into the woodland. On the other hand, some species such as M. muehni, Oxysarcodexia marina (Hall, 1938) and Helicobia aurescens (Lahille 1907) were captured in similar or higher numbers on liver (Table 1).

Effect of temperature on flies abundance: the overall number of flesh flies per sample 

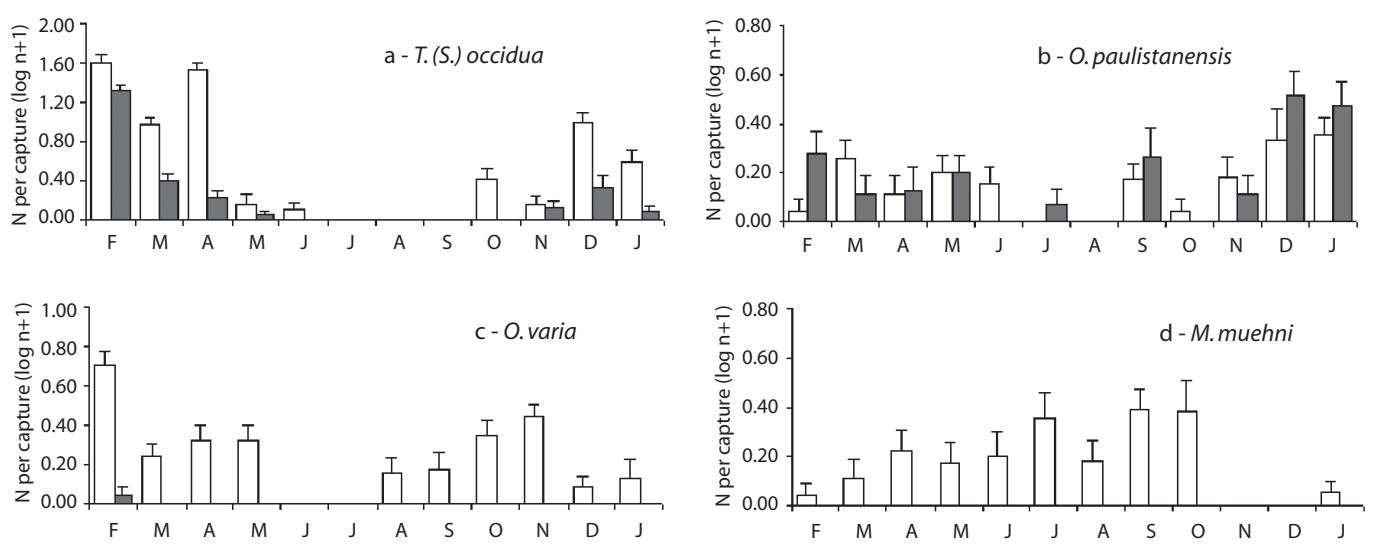

Fig. 2. Seasonal abundance (mean $\pm \mathrm{SE}$ ) of Tricharaea (S.) occidua (a), Oxysarcodexia paulistanensis (b), Oxysarcodexia varia (c), Microcerella muehni (d) captured in woodland (black bars) and grassland (white bars) at RECS (February 2004-January 2005).

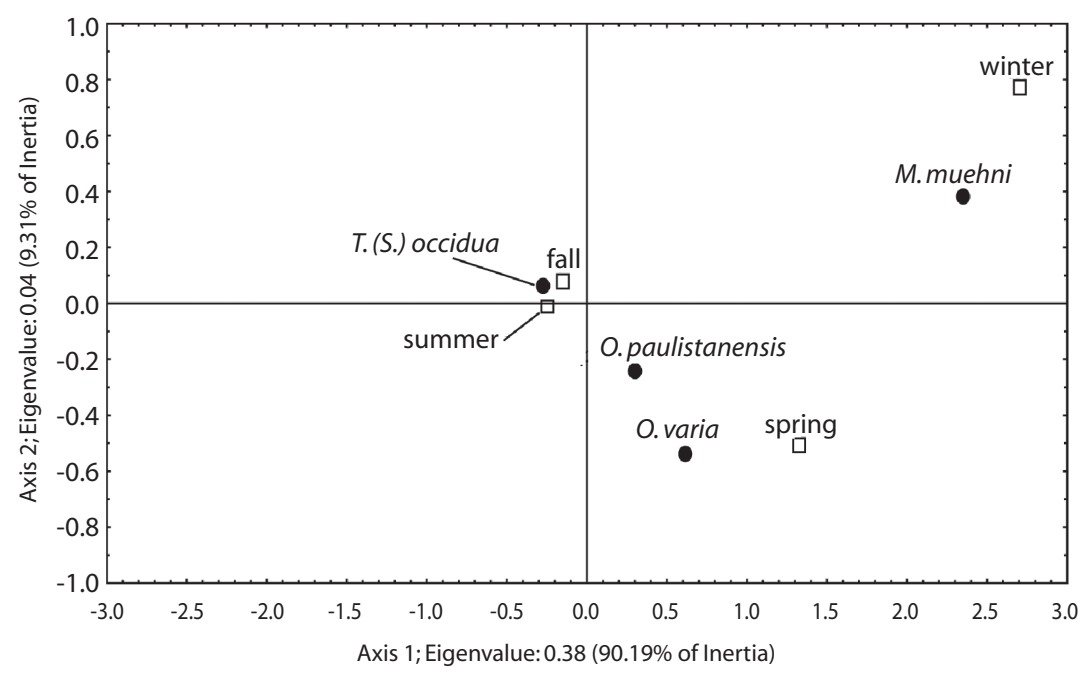

Fig. 3. Correspondence Analysis (CA) ordination diagram of the first two axes of the abundant species of Sarcophagidae (black circles) captured in different seasons (white squares) at RECS.

was positively correlated with the mean temperature recorded at RECS in both surveyed habitats. The same result was found when data of grassland habitat and woodland were combined in a single analysis (Fig. 4).

At species level, the abundance of $T$. (S.) occidua $(\mathrm{r}=0.50, \mathrm{~N}=83, \mathrm{p}<0.05)$ and $O$. paulistanensis $(\mathrm{r}=0.49, \mathrm{~N}=83, \mathrm{p}<0.05)$ was positively correlated with mean temperature, while $M$. muehni showed a negative correlation with temperature $(\mathrm{r}=-0.41, \mathrm{~N}=83, \mathrm{p}<0.05)$. O. varia did not show a clear pattern $(\mathrm{r}=0.14, \mathrm{~N}=83$, $\mathrm{p}>0.05$ ).

\section{DISCUSSION}

The relationship between flesh flies overall abundance and temperature suggests that both variables are positively correlated given that the higher numerical peaks are achieved in 


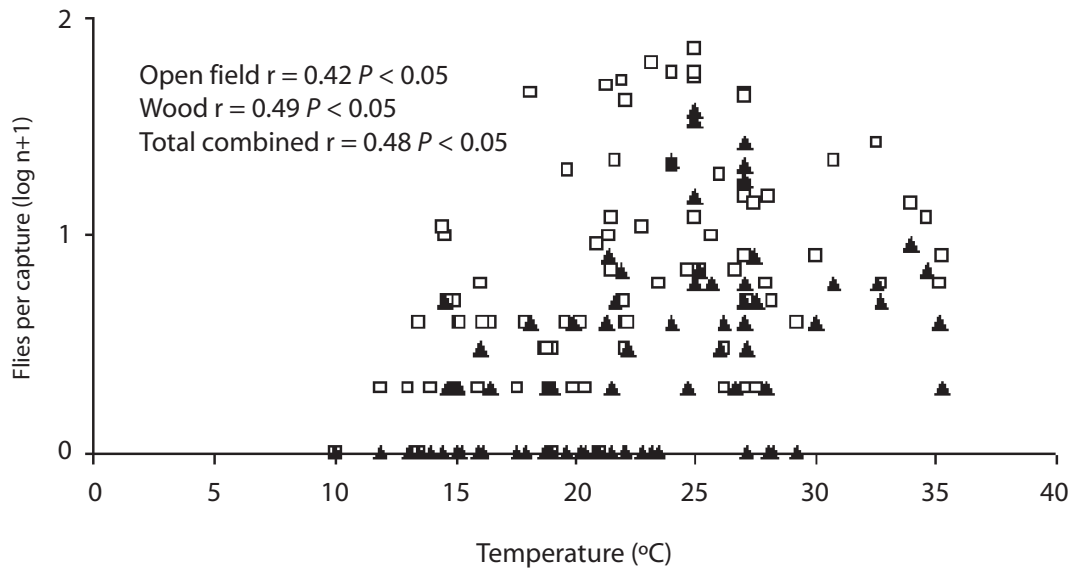

Fig. 4. Relationship between mean temperature and total flesh flies abundance per catch at RECS (February 2004-January 2005). White squares and black triangles indicate captures in grassland and woodland, respectively.

late spring and in summer. Assuming that this pattern is related to temperature it is cogent to speculate that most of the recorded species be thermophilic. A positive and significant correlation with temperature was estimated for $T$. (S.) occidua and O. paulistanensis and would be eventually expected for other species, like Ravinia sueta (Wulp 1895) Nevertheless, the low relative importance of the latter does not necessarily indicate a positive correlation between its abundance and temperature. Conversely, the abundance of M. muehni was inversely related to temperature being therefore the only recorded species which would be regarded as thermophobic. Correlation between temperature and abundance was not observed in $O$. varia.

Sarcophagidae, including the most abundant species found at RECS, O. paulistanensis and $T$. (S.) occidua, did not show definite temporal trends all the year long in Belo Horizonte, Minas Gerais, Brazil (Dias et al. 1984a, b), where the climate is subtropical and dry. It would be suggested that the highest abundance of flesh flies recorded in spring-summer and early fall in the RECS may be due to this region wider thermal differences between summer and winter. Moreover, it would support the assumption that thermophily can better be demonstrated in temperate regions than in tropical and subtropical ones. However, no seasonal changes have been observed in flesh fly communities in Curitiba, Paraná, a Brazilian city with a humid-temperate climate (Ferreira 1979), whose mean annual temperature $\left(16.6^{\circ} \mathrm{C}\right)$ is slightly lower than in Buenos Aires $\left(17.6^{\circ} \mathrm{C}\right)$. In spite of this, climatic factors other than temperature could partially explain these geographic different seasonal patterns. For example the highest rainfall in the referred Brazilian localities takes place in summer, while in Buenos Aires the rain are more intense in winter. Previous works about population abundance of Calypterate Diptera showed that some species numerical trends are positively correlated with temperature (Oliveira et al. 2002, Henning et al. 2005).

Despite the above comments, the lowest temperatures recorded during the winter in RECS did not seem to be a total restriction to flesh flies activity, given Sarcophagidae were recorded in all samples. Even so, thermophilic species like T. (S.) occidua may spend their immature instars buried into the soil's upper layers during winter, emerging as adults during spring. Poor adaptation to cold temperature was reported for Sarcophaga (Liopygia) argyrostoma (Robineau-Desvoidy 1830) which did 
not complete its development or spent much more time to reach the adult stage at low temperatures (Grassberger et al. 2002). Within this family a variety of adaptive responses to temperature has been acknowledged. A remarkable example is shown by the genus Microcerella whose seventy three species are mainly distributed in Andean or Patagonian habitats (Mariluis 2006) where extremely low temperatures is a climatic normal feature .

The obtained results have shown that the dominant flesh fly species display a stronger preference for grassland habitat where the incidence of sunlight is direct, than for the shaded woodlands. Although the exclusive occurrence of some rare species, like Nephochaetpopterix elegans (Blanchard 1939), O. bicolor Lopes 1946 and $R$. sueta in the woodland may reflect a strong association with this type of habitat, the low records of these species does not allow us to suggest a definite habitat preference.

The higher numerical occurrence of flesh flies associated to dog faeces than to cow liver agrees with recently studies undertaken in the RECS (Mariluis et al., in press).

Concerning the flesh fly community organization, more than $85 \%$ of the thirteen woodland's and $87 \%$ of the twelve open field's recorded species expressed the cumulative abundance of only two and three species, respectively. Therefore, the observed species arrangement at both sites -of very similar species richness- indicates a low species diversity and equitability and a remarkably high information per individual in the average. The referred community structure would indicate the possible effects of environmental disturbance due to their proximity to dense urban settlements. However, further studies of similar habitats from the same geographic location but away from human influence are needed to assess whether the observed community traits are influenced by anthropic factors or they are simply due to the way flesh fly species arrange themselves within the community structure.

\section{ACKNOWLEDGMENTS}

We thank the authorities of the RECS for allowing us to sample within this protected area. We are indebted to the Technical and Scientific National Research Council of Argentina (CONICET) for funding this research.

\section{RESUMEN}

Variaciones numéricas de especies de Sarcophagidae (Diptera) se registraron durante un año a intervalos mensuales (febrero 2004-enero 2005), en un pastizal y un bosque de la "Reserva Ecológica Costanera Sur" (RECS) de la ciudad de Buenos Aires. Se realizaron capturas horarias (10:00 am - 04:00 pm) en cada fecha de muestreo. La muestra de todo el año acumuló 1305 individuos y 18 especies. Estos dípteros fueron más abundantes en el pastizal que en el bosque. Las especies más numerosas fueron: Microcerella muehni, Oxysarcodexia paulistanensis, O. varia y Tricharaea (Sarcophagula) occidua, en tanto que las restantes representaron menos de $8 \%$ del total. La mayoría de las especies mostraron preferencia por las heces como cebo. Las especies dominantes, con excepción de la especie termofóbica $M$. muehni, prevalecieron en la primavera tardía y en el verano. La alta dominancia específica observada podría ser indicativa del desorden ecológico provocado por la influencia de asentamientos urbanos adyacentes a los sitios de muestreo.

Palabras clave: Sarcophagidae, Buenos Aires, pastizal, bosque, composición específica, abundancia estacional.

\section{REFERENCES}

Blanchard, E.E. 1939. Los sarcofágidos argentinos, contribución a su conocimiento. Physis 17: 791-856.

Blanchard, E.E. 1942. Los sarcofágidos argentinos, segunda contribución a su conocimiento. Physis 19: 133172 .

Dias, E.S., D.P. Neves \& H.S. Lopes. 1984a. Estudos sobre a fauna de Sarcophagidae (Diptera) de Belo Horizonte, Minas Gerais. I. Levantamento taxonómico e sinantrópico. Mem. Inst. Oswaldo Cruz 79: 83-91.

Dias, E.S., D.P. Neves \& H.S. Lopes 1984b. Estudos sobre a fauna de Sarcophagidae (Diptera) de Belo 
Horizonte, Minas Gerais. II. Variação sazonal. Mem. Inst. Oswaldo Cruz 79: 409-412.

Ferreira, M.J.M. 1979. Sinantropia de dipteros muscoideos de Curitiba. II: Sarcophagidae. Rev. Brasil. Biol. 39: 773-781.

Guimarães, J.H., N. Papavero \& A.P. do Prado. 1983. As miiases na região Neotropical: Identificação, Biologia, Bibliografia. Rev. Brasil. Zool. 1: 239-416.

Grassberger, M. \& C. Reiter. 2002. Effect of temperature on development of Liopygia (=Sarcophaga) argyrostoma (Robineau.Desvoidy) (Diptera: Sarcophagidae) and its forensic implications. J. Forensic Sci. 47: 1-5

Greenberg, B. 1971. Flies and Disease vol. 1: Ecology, Classification and Associations. Princeton, Princeton University, Princeton, New Jersey, USA.

Henning, J., F.R. Schnitzler, D.U. Pfeiffer \& P. Davies. 2005. Influences of weather conditions on fly abundance and its implications for transmission of rabbit haemorrhagic disease virus in the North Island of New Zealand. Med. Vet. Entomol. 19: 251-262.

Ives, A.R. 1991. Aggregation and coexistence in a carrion fly community. Ecol. Monogr. 61: 75-94.

Linhares, A.X. 1981. Synanthropy of Calliphoridae and Sarcophagidae (Diptera) in the city of Campinas, São Paulo, Brazil. Rev. Brasil. Entomol. 25: 189-215.

Lopes, H.S. \& R. Tibana. 1987. On Oxysarcodexia (Diptera, Sarcophagidae), with descriptions of five new species, key, list and geographic distribution of the species. Rev. Brasil. Biol. 47: 329-347.

Mariluis, J.C. 2006. Description of a new species of Microcerella (Diptera: Sarcophagidae) from Argentinean Patagonia. Zootaxa 1124: 47-53.
Mariluis, J.C., J.A. Schnack, P.R. Mulieri \& J.P. Torretta. 2007. The Sarcophagidae (Diptera) of the Coastline of Buenos Aires City, Argentina. J. Kansas Entomol. Soc. 80: 243-251.

Mazza, S. \& R. Basso. 1939. Miasis de úlcera crónica de pierna por Sarcophaga barbata y Cochliomyia hominivorax (Investigaciones sobre dipteros argentinos. I. Miasis). Misión Estudios de Patología Regional Argentina Jujuy 41: 47-54.

Mazza, S., S. Parodi \& C.M. Smith. 1930. Miasis ocular por larvas de Sarcophaga sp. 5a. Reunión de la Sociedad Argentina de Patología Regional. Norte 2: 1157-1159.

Mendes, J., A.X. Linhares. 1993. Sazonalidade, preferência por iscas e desenvolvimento ovariano em várias espécies de Sarcophagidae (Diptera). Rev. Brasil. Entomol. 37: 355-364.

Oliveira, V.C., J.M. d'Almeida, M.J. Paes \& A. Sanabria. 2002. Population dynamics of calypterate Diptera (Muscidae and Sarcophagidae) at the Rio-Zoo Foundation, Rio de Janeiro, RJ, Brazil. Brazilian J. Biol. 62: 191-196.

Pape, T. 1996. Catalogue of Sarcophagidae of the world (Insecta: Diptera). Mem. Entomol. Int. 8: 1-558.

Wells, J.D., T. Pape \& F.A.H. Sperling. 2001. DNA-based identification and molecular systematics of forensically important Sarcophagidae (Diptera). J. Forensic Sci. 46: 1098-1102.

Zar, J.H. 1996. Biostatistical Analysis. New Jersey, Prentice Hall, New Jersey, USA.

Zumpt, F. 1965. Myiasis in Man and Animals in the Old World. London, Butterworths, London, England. 